Article

\title{
The Evolutionary Model of Corporate Entrepreneurship: A Case Study of Samsung Creative-Lab
}

\author{
Bo Young Shin ${ }^{1}\left(\mathbb{D}\right.$ and Keun Tae Cho ${ }^{2, *}$ \\ 1 Graduate School of Management of Technology, Sungkyunkwan University, Chunchundong 300, \\ Suwon 440-746, Korea; sin2688@naver.com \\ 2 System Management Engineering \& Graduate School of Management of Technology, \\ Sungkyunkwan University, Chunchundong 300, Suwon 440-746, Korea \\ * Correspondence: ktcho@skku.edu; Tel.: +82-031-290-7602
}

Received: 15 October 2020; Accepted: 28 October 2020; Published: 30 October 2020 updates

\begin{abstract}
Despite international interest in corporate entrepreneurship research, relevant knowledge has not been systematically accumulated. Even in practice, the discussions of corporate entrepreneurship revolve around the appropriate level necessary and the preferred method of action. This paper proposes an evolutionary model that outlines corporate entrepreneurship overall in terms of an organization's entrepreneurial activities. For the research objective, this paper includes in-depth case studies on Samsung's Creative Lab. The Creative-Lab of Samsung has been actively implementing corporate venture system for eight years. We conducted collective case studies by focusing on a single case (Creative-Lab) and then moving to multiple cases (Creative-Lab spin-off companies). Firstly, the study identifies the development process of entrepreneurship from the individual-level to the firm-level, and from the firm-level to the social-level. Secondly, the study confirms that corporate venturing and the corporate spin-off system have a positive impact on entrepreneurial behavior, which is crucial to seize opportunities. Thirdly, based on the growth factors and performance of corporate entrepreneurship, an evolutionary model of corporate entrepreneurship is proposed in this paper. This study can contribute to the establishment of an integrated and structured mechanism of related research as it comprehensively reviews the antecedents, elements, and outcomes of corporate entrepreneurship.
\end{abstract}

Keywords: corporate entrepreneurship; entrepreneurial orientation; corporate venturing; corporate spin-off; opportunity seizing; innovation

\section{Introduction}

As the unexpected COVID-19 crisis accelerates to constitute the new normal, there is a need to look back to the situation that prevailed during the 1970s and 1980s in the US. Overcoming the economic downturn that lasted from 1970 to the first half of the 1980s, the US economy recovered remarkably from mid-1980s. Focusing on the outcome, namely the creation of more than 40 million jobs, which was contrary to every experts' expectations, Drucker [1] stresses that the driving force for this resurgence was entrepreneurship. Drucker presents the sources and opportunities, which were needed for innovation when the US economy shifted from a managed economy to an entrepreneurial one and demonstrates how individuals at their end can exercise entrepreneurship.

The economist George Schumpeter [2], the first to mention entrepreneurship, emphasized innovation as the driving force behind capitalist economic development, and considered entrepreneurship as the source of innovation. At the time, Schumpeter was the only major economist 
to pay attention to the impact of entrepreneurship on economy. While the other economists recognized the importance of entrepreneurship, however, they did not consider it as a component of economy [1]. In addition, based on Gartner's [3] claim that entrepreneurship is the ability to recognize, discover, and exploit opportunities and an activity to create new organizations, related research has expanded to include external environmental factors as well as founders' inner tendency.

In the 2000s, we witnessed Steve Jobs revolutionizing the industrial world. In 2007, the creation of the iPhone was a result of capturing new business opportunities and creating unprecedented value through innovative thinking and behavior. Another example is that of LinkedIn, a business social networking services platform, generated \$26 billion in corporate value. Reid Hoffman, co-founder of LinkedIn, emphasized organizational flexibility; he says entrepreneurship is "you throw yourself off a cliff and assemble your airplane on the way down" (p. 103, [4]). As such, entrepreneurship today places more emphasis on the "organizational ability to execute" than on the "brilliant idea of a genius."

The new normal post COVID-19 is soon arriving. The untact trends and the acceleration of digitalization present tasks to companies, which they must carry out in order to cope with the trials and tribulations of the post-corona era. At this point, there is a need to remind ourselves of the importance of entrepreneurship and take proactive actions of the firm-level. Drucker (p. 135, [1]) argues that "Innovation is both conceptual and perceptual. The imperative of innovation is therefore to go out to look, to ask, to listen. Successful innovators are opportunity-focused." Hence, we should seek opportunities in the new-found situation and respond to the new normal.

There is no independent and agreed framework for entrepreneurship. This is especially true of corporate entrepreneurship (CE), which is a firm-level entrepreneurship. While international interest in academic research has increased tremendously, relevant knowledge has been fragmented and lacked systematic accumulation [5-8]. This is firstly because the nature of the research subject varies depending on the industrial sector, and the purpose of the project, the expected performance, and the methodology of the research differ with each other, making it difficult to reach a conceptual consensus [9]. Secondly, while entrepreneurship has a strong practical aspect, it lacks case studies, making it difficult to theorize the phenomenon.

Nevertheless, the importance of CE has come to gain great emphasis, with it being one of the most interesting topics for corporate researchers. The first reason for this is that, as a business management activity, CE reflects the characteristics and trends of the industrial sector, the size of the entity, the national characteristics, and the particularities of the times. Second, as a strategic measure for corporate survival and sustainable growth, discussions continue as to what the appropriate level is and how can one implement it [6,9]. In order to answer these two questions, studies on CE's manifestation process and specific context should proceed in terms of entrepreneurial activity. Based on this, an integrated and structured mechanism that covers CE as a whole will need to be established. However, few studies closely examine and comprehensively analyze CE in terms of activity. The biggest gap in the related research is the lack of a structured, representative, and comprehensive theory covering entrepreneurship as a whole. It is important that the efforts to build this need are reinforced [10].

The objective of this study is to propose the evolutionary model of CE that outlines the entire CE as an entrepreneurial activity. As a basis, this study analyzes the system and technology management activities in-depth for "Samsung Electronics' Creative-Lab (C-Lab)", which is a representative CE activity in Korea. The study focuses on the contextual understanding of "why" and "how" and on the significance of each activity. By focusing on how CE develops within large enterprises and how corporate venturing and corporate spin-off systems affect the seizing of opportunities, our ultimate research objective can be achieved. In addition, the results of this study can contribute to the building of the CE mechanism. 


\section{Literature Review}

\subsection{Entrepreneurial Orientation and Corporate Entrepreneurship}

The interest in and importance of $\mathrm{CE}$ is increasing as an effective way to improve the performance of enterprises. This is because more entrepreneurial activities of the firm-level are required to secure competitive advantage [11,12]. Entrepreneurship of the firm-level, not individuals, is called CE [13]. $\mathrm{CE}$ is a forward-looking, innovative, and risk-taking corporate policy that includes the proactive attitude and behavior of all members. It is also a key factor in solving corporate bureaucratic problems such as inefficiency or avoidance of responsibility. In other words, even bureaucratic large enterprises can innovate through entrepreneurial thinking and actions of the firm-level. In addition, CE has become a key means to accumulate, transform, and utilize an organization's resources [14].

CE's typical organizational concepts are largely divided into two main categories: Entrepreneurial characteristics and entrepreneurial activities. The most comprehensive approach to entrepreneurship was led by Miller [15], who divided entrepreneurial characteristics into innovativeness, proactiveness, and risk taking. The concept was subsequently developed by Covin and Slevin [16] as entrepreneurial posture, which was further expanded by Lumpkin and Dess [17] into entrepreneurial orientation. Lumpkin and Dess [17] defined the five components of entrepreneurial orientation by adding autonomy and competitive aggressiveness to innovativeness, proactiveness, and risk taking. From the arguments of Covin and Slevin [16], entrepreneurship already means the concept of the firm-level, not the individual-level. The concept of $\mathrm{CE}$ has since then continued to expand and strengthen at the firm-level.

Guth and Ginsberg [18] have defined CE in terms of an organization's entrepreneurial activities. This includes creating new businesses through innovation or venturing within existing organizations and changing organizations through strategic renewals. Following Guth and Ginsberg's [18] research concept, Zahra $[19,20]$ has defined CE as "the sum of a company's innovation, strategic renewal and corporate venture activities." According to him, strategic renewal comprises of a wide range of corporate institutions and policies, which include redefining the concept, scope, and competition method of the business and redeploying the resources, which could maximize the generation of creative value. He also argues that CE has a positive impact on a company's financial performance and plays an important role in its survival and growth. Focusing on the entrepreneurial activities within the organization, Sharma and Chrisman [13] p. 18 tried to develop CE into an independent academic field, conceptualizing it as "the process whereby an individual or a group of individuals, in association with an existing organization, create a new organization or instigate renewal or innovation within that organization."

There was a study that analyzed the past 40 years of research on CE in terms of entrepreneurial activity [11]. Related research in the 1970s focused on how entrepreneurship could be expressed within the existing organizations. Further, in the 1980s, CE was conceptualized to include organizational separation and resource allocation. It was however, in the 1990s that a significant change in the perception of entrepreneurial behavior took place. At the time, companies required practical entrepreneurial behavior in terms of business reorganization and efficient utilization of resources, and researchers also focused on $\mathrm{CE}$ as a practical means to enhance capabilities and improve the performance of the enterprise. Later, in the 2000s, the concept of entrepreneurial behavior came to be established as a set of entrepreneurial activities that seize opportunities in uncertain situations.

In addition, Ireland et al. [5] have proposed CE strategy as a means to revitalize the organization deliberately and continuously. The primary components of the $\mathrm{CE}$ strategy are divided and conceptualized here as "antecedents, elements, and outcomes," and the model for the overall CE strategy is presented by linking their relationships. The study also emphasizes the entrepreneurial organizational structures and entrepreneurial behavior of seeking opportunities as the key elements and success factors of CE strategy.

As shown above, research on CE has shifted its focus from an individual's entrepreneurial orientation to an organization's entrepreneurial activity. This is because individual entrepreneurship by itself cannot meet the rapidly changing business environment and the demands of various markets. Entrepreneurial 
orientation is a fundamental component of CE [21-23], and representative entrepreneurial activities can be defined as corporate venturing and strategic renewals [13]. These entrepreneurial activities also lead towards the seizing of opportunities. As a result, since the 2000s, research on CE has expanded into a variety of topics, including opportunity capturing, opportunity realization, start-up, and venture growth. Also, an increasing number of studies are interpreting and evaluating them in connection with the sustainable competitive advantage of enterprises [11].

Despite the quantitative increase in related studies, there is still a lack in research efforts to interpret CE in terms of an organization's entrepreneurial activities [7]. Also, there have been negative opinions raised concerning CE. Some argued that it is due to the bureaucratic organizational structure that entrepreneurial characteristics cannot be properly realized in large corporations [17], the others have carried out studies to understand the reverse U-shaped relationships between CE and corporate performance $[9,24]$. If CE's opportunity cost is greater than the positive effect, it can lead to financial losses, and a significant expectation may have a negative impact on the organization's operations.

As such, detailed theoretical and empirical knowledge on entrepreneurial behavior, on which $\mathrm{CE}$ is based, is required. Kuratko et al. [7] pointed out that the study of CE's specific practice methods and development directions should be focused on in the future. "How to institutionalize, operate, and manage $\mathrm{CE}$ concepts in terms of organizational activities, and finding out the challenges companies face and exploring the way to overcome them" are the research topics as important as the conceptualization of CE. Such research should comprehensively include not only the allocation of human resources, but also the institutionalization measures for $\mathrm{CE}$, operation and management of the system, and environmental and industrial issues surrounding it. Thus, efforts should be made to check the current status of recent research focusing on corporate venturing, which is CE's representative activity, and further develop corporate venturing systems and processes via case studies.

\subsection{Corporate Venturing and Corporate Spin-off}

There is no agreed upon conceptual definition of corporate venturing. While abstract terms are concretized with the passage of time, relevant new phenomena are being added. In general, corporate venturing means "an independent organization within an organization that creates new business by using internal resources" $[25,26]$. Burgelman [21] states that corporate entrepreneurship is a process of creating a kind of corporate venturing, asserting the existence of a close link between entrepreneurship and corporate venturing, and proving that entrepreneurship is a variable for organizational innovation and corporate competitiveness. The most important mark of corporate venturing is an independent organization, which is closely related to corporate innovation and strategic renewal and contributes towards the creation of new businesses [13]. However, corporate venturing is distinguished from innovation or strategic renewal, in that it focuses on the various processes required to create new businesses [6]. Kuratko et al. [7] argue that corporate entrepreneurship is an approach that involves implementation with the aim of seizing opportunities, and corporate venturing activities are the main pillars for realizing CE. As for the effectiveness of corporate venturing, some are of the view that it not only promotes innovation when it is difficult to do so within existing organizations with already established scale and frameworks, but also serves as a source for new ventures [27]. In summary, "corporate venturing is the main activity of $\mathrm{CE}$ and is the set of the organizational systems, processes, and practices that focus on creating business in existing or new fields, markets or industries" (p. 59, [6]). Its results range from creating new businesses to seizing opportunities, creating enterprises, and promoting innovation.

In addition, related research primarily focuses on the characteristics, operational guidelines, and performance of corporate venturing. Interest in the national and organizational context of operating corporate venturing has been notably growing in the recent past. This is because corporate venturing not only allows the entity to develop new capabilities and create sources of innovation value, but also to derive leverage effects that make better use of existing assets and capabilities [8]. 
Despite being a key component of $\mathrm{CE}$, research on corporate venturing is relatively insufficient. As with CE studies, the lack of a common framework and measurement and limited alignment with major theoretical trends are impediments for in-depth studies [6,8]. In addition, inconsistencies in temporal dynamics can hinder the development of corporate venturing. The inconsistency in temporal dynamics is that the time required for corporate venturing to prove its viability is quite long, around 8-12 years on average, while the time required for companies to participate in corporate venturing activities is usually shorter [28]. In addition, frequent changes in the degree of belief and support for corporate venturing activities do not produce optimal results for enterprises [21]. Thus, most of the corporate venture activities are still in the introductory stage, and there are significantly fewer subjects available that can be used as samples for case studies. As such, research on corporate venturing is very difficult. While it is easy to criticize the methodology of a study, it is highly difficult to adequately address a complicated research subject [8]. Nevertheless, the accumulation of relevant knowledge requires efforts to collect various samples, carry out comparative analysis, and make generalizations.

In a broad sense, corporate spin-off is also included in the corporate venturing strategy [13,29]. In management, corporate spin-off is a type of start-up enterprise, which is a separate and independent business from the parent organization, such as a university or enterprise. As a representative type of start-up company, it is considered as a meaningful social phenomenon that contributes toward national economic development, industrial innovation, and job creation [30,31].

Spin-off companies are divided into two types: Research-based spin-off companies with research-oriented universities and public research institutes as their parent organizations, and corporate-based spin-off companies with companies as their parent organizations. Among them, studies show that corporate-based spin-off companies generally perform better and have greater ripple effects than research-based spin-off companies [30,32,33]. This is because technology is the main competitive advantage for research-based spin-off companies, while various factors such as products, markets, marketing, and management are the sources of competitive advantage for corporate-based spin-off companies. However, the accumulated findings on corporate-based spin-offs are very sparse, and there is little theoretical basis for success factors or reasons for failure [30]. In addition, a majority of the existing literature is that of case studies of US corporate restructuring, and the objectives and focuses of research are somewhat disconnected from CE activation. Also, the characteristics and success factors of research-based and corporate-based spin-off companies are different. Nevertheless, there has been a research approach that does not take into consideration the differences between the two [31]. Accordingly, more research is needed on corporate-based spin-off companies.

As such, entrepreneurial orientation and CE, corporate venturing, and corporate spin-off are not individual concepts. Nevertheless, few studies have systematically and comprehensively analyzed related phenomena and derived CE activation plans $[5,6,34]$. This is a significant limitation of existing research, which does not contribute towards the accumulation of knowledge and development of theories as most results of entrepreneurship studies are fragmented [35]. These superficial and fragmented findings are also difficult to generalize in practice. As a more proactive CE activity, research is needed to expand and develop the performance of corporate venturing toward corporate spin-off and verify its validity.

\section{Materials and Methods}

\subsection{Research Model}

In this study, the entrepreneurship of spin-off company is expected to be promoted and manifested through the process of Figure 1. In Figure 1, the horizontal axis represents the antecedents, elements, and outcomes (left to right), which are the components of CE activity, and the vertical axis represents the level of expansion (bottom to top) of CE area from individuals to markets and industries. If the previous studies have confirmed that $\mathrm{CE}$ evolves from individual-level entrepreneurial orientation to organizational-level entrepreneurial activity, this study will attempt to explore how organizational-level 
entrepreneurial activities develop into market- and industry-level innovative values. In other words, it was confirmed through the existing studies that CE begins with an individual's entrepreneurial orientation, and that it can be expressed as a specific entrepreneurial activity at the organizational level via the corporate venturing system. Furthermore, this study includes the corporate spin-off system as a way to expand the performance of the corporate ventures to the social-level and tries to confirm its validity through case studies. In Figure 1, what was confirmed through the previous studies is indicated by a solid line, and those that need to be further confirmed through this study are indicated by a dotted line. Corporate spin-off will enable companies to generate financial and non-financial performance and create unprecedented innovative value. In addition, if external environmental factors such as demand in products and markets, advance of related technologies, national support policies, and strategic cooperation between companies are added, CE will finally be able to develop into a form of realizing innovative values.

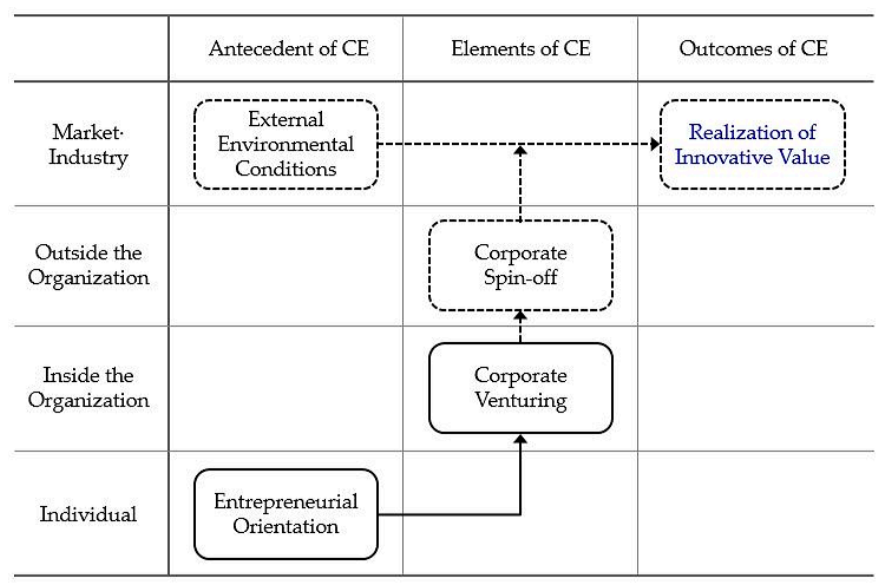

Figure 1. Research model.

\subsection{Research Method}

The best way to study CE as a whole is through qualitative research [21]. In this study, a case study was conducted to understand CE's context by closely examining its development process and examine dynamic the phenomena that are difficult to examine with statistical means. This research method can be applied when a complex and detailed understanding of an issue is required, and is effective in explaining the methods, processes, and reasons for a particular subject [36,37]. It can also reveal the interactions between important elements that characterize the phenomenon or help in gaining new insights that overcome the limitations of existing research [38]. The reason why case studies are drawing attention in the field of business administration is that as the business environment becomes more complex, alongside the rapid changes in the industrial paradigm, there are growing phenomena that are difficult to measure and interpret with the existing theories [37,39,40].

Thus, a collective case study was conducted through qualitative data analysis. The case study was performed in accordance with the 8-step case study procedure of Eisenhardt [36], a representative case study method. The detailed procedures for the case study are demonstrated in Table 1.

Corporate venturing is relatively less likely to succeed than the existing organizations, and even if successful, it will take 3-8 years to achieve meaningful results [25]. Accordingly, this study purposively sampled Samsung C-Lab as a representative example of corporate venturing and chose it as a research subject. This is because Samsung C-Lab is a case of a large enterprise that has been operating a corporate venturing system continuously and actively for more than eight years, and the C-Lab's process of finding, implementing, and commercializing ideas are systematically operated. This is a case of centralized corporate venturing and belongs to internal corporate venturing, wherein the ideas arise from the parent company. 
Table 1. Research process.

\begin{tabular}{ll}
\hline \multicolumn{1}{c}{ Research Phase } & \multicolumn{1}{c}{ Major Activities } \\
\hline 1. Research initiation & Case study on CE development process and components \\
\hline 2. Case selection & $\begin{array}{l}\text { Selecting a large enterprise that actively operates a corporate venturing } \\
\text { Target: (1) Samsung Electronics C-Lab, (2) C-Lab Spinoff: 4 companies }\end{array}$ \\
\hline 3. Design of research method & $\begin{array}{l}\text { (1) Document analysis: press data on Samsung C-Lab and spin-off companies } \\
\text { (2) Interview: preparing for interview protocols and questionnaires, confirming targets }\end{array}$ \\
\hline 4. Field survey & $\begin{array}{l}\text { Visit corporate sites } \\
\text { Conduct face-to-face interviews with the founders of 4 spin-off companies }\end{array}$ \\
\hline 5. Data analysis & $\begin{array}{l}\text { Apply the grounded theory analysis procedure by Strauss and Corbin [41] } \\
\text { Detailed code classification (minor category) } \rightarrow \text { category classification (middle } \\
\text { category) } \rightarrow \text { central thematization (major category) }\end{array}$ \\
\hline 6. Derivation of proposition & $\begin{array}{l}\text { Derive the growth factors and performance of CE through corporate spin-off } \\
\text { Establish the evolutionary model }\end{array}$ \\
\hline 7. Literature comparison & Proposal on how to overcome CE's negative views and limitations \\
\hline 8. End of study & Present the academic contributions and practical implications of this study \\
\hline
\end{tabular}

\subsection{Data Collection and Data Analysis}

The data collection process was divided into stages; the first stage of document analysis and the second stage of interview. In the first stage of document analysis, the development process of Samsung C-Lab was researched. Based on the experience of the researcher who participated in the planning and project operation of the system for 4 years, right from the start of C-Lab, a total of 156 documents were collected and the major activities and development processes of C-Lab were analyzed. Document collection was based on: (1) Samsung Electronics Newsroom [42], (2) Samsung Electronics Sustainability Report (2013-2020) [43], (3) C-Lab related articles and analyst reports (DBR [44], etc.) published in media, and (4) webpage information and internal data of each spinoff company.

In the second stage of data collection, the research subject was expanded to C-Lab spin-off companies, and in-depth interviews were conducted with the founders of four representative spin-off companies. This was to be used to verify the validity of the organization's outside and the market and industry (dotted line) presented in Figure 1. All four spin-off companies were in the growth phase (3-7 years after their founding) and were set to get into the full swing for business. The interviews were conducted four times from June to July 2020; they were conducted on the basis of semi-structured questionnaires, which took over 3-4 $\mathrm{h}$ for each company to complete. The growth stage of companies is divided into start-up preparation (C-Lab), start-up period (start to 3 years), and growth period (4-7 years). Further, in-depth questions were asked about the crises, opportunity factors, and the ways to overcome the challenges that the companies experienced at each stage. Through this, the study was able to further identify the phenomena that were not revealed in the documents and learn about the specific experiences of seizing opportunities. Table 2 presents the primary status of interview companies.

In the data analysis stage, keywords related to CE were derived based on the collected documents and interviews of the four spin-off companies. Significant words repeatedly mentioned were listed, and data coding was performed based on the grounded theory analysis developed by Strauss and Corbin [41]. Specifically, codes and categories were derived, and the topics were schematized through subject-specific connections. A total of 127 keywords were derived from the collected data, including idea, execution power, challenging spirit, creative organizational culture, and opportunities to create businesses. These underwent a refining process, which included integration of similar words. Subsequently, 22 keywords representing CE growth factors and performance were derived. The CE evolutionary model was completed by dividing these 22 keywords into antecedents, elements, and outcomes of $\mathrm{CE}$ and linking their relationships. 
Table 2. Key status of interviewed companies.

\begin{tabular}{|c|c|c|c|c|}
\hline Content & Company A & Company B & Company C & Company D \\
\hline Time of establishment & 2015. 08 & 2015. 08 & 2016. 06 & 2016. 11 \\
\hline Industry & $\begin{array}{c}\text { IT (audio) } \\
\text { Beauty appliance }\end{array}$ & AI Shoes & $\begin{array}{c}\text { IT } \\
\text { (smart appliance) }\end{array}$ & IT (security) \\
\hline Corporate growth phase & Growth period & Growth period & Growth period & Growth period \\
\hline Representative's major & Brain engineering & $\begin{array}{c}\text { Electric } \\
\text { engineering }\end{array}$ & $\begin{array}{l}\text { Computer } \\
\text { science }\end{array}$ & Computer science \\
\hline Representative's gender & M & M & M & M \\
\hline Representative's age & 38 & 36 & 40 & 45 \\
\hline Number of co-founders & 2 & 3 & 3 & 4 \\
\hline Number of employees & 14 & 19 & 17 & 40 \\
\hline Customer type & B2B-oriented & $\mathrm{B} 2 \mathrm{~B} / \mathrm{B} 2 \mathrm{C}$ & B2B-oriented & $\mathrm{B} 2 \mathrm{~B}$ \\
\hline Global presence & US & US, Japan & $\begin{array}{l}\text { US, Japan, etc. } \\
\text { Seven countries }\end{array}$ & China, Japan \\
\hline
\end{tabular}

This study includes seven of the eight reliability criteria proposed by Lincoln and Guba [45]. While case studies typically include three or four of these criteria for internal validity and reliability, this study included seven:

1. Concentrated observation over a sufficient period of time: Based on corporate documents related to the field conditions experienced directly or indirectly by the researcher for four years, such as attendance at the CEO's report meetings, drafting of plans, and committee meeting minutes.

2. Triangulation: Reduce methodical and analytical errors by applying multiple research methods such as observation of participation, document analysis, and interviews.

3. In-depth description: Improving the generalization of data analysis via activities such as description of the context of the action, statement of intent and meaning behind the act, description of the progress of the action, and interpretation of the situation.

4. Use of reference materials: Data coding for document analysis results and interview details.

5. Advice from fellow researchers: Accepting criticism from fellow researchers and reflecting alternative ideas through workshops.

6. Member check: Study participants' compliance with the verification procedure and reflection of the participants' opinions on interpretation.

7. Reviewing the opposite view: Comparison with the negative views on $\mathrm{CE}$, such as the relationship with performance.

In addition, multiple case studies were conducted on the 4 entities to enhance their external relevance.

\section{Results}

\subsection{C-Lab System}

\subsubsection{Status and Performance}

Introduced in December 2012, Samsung C-Lab is a corporate venturing system that helps in spreading creative organizational culture and discovering creative ideas. If the proposed idea is adopted after a public review, the idea proposer can focus on commercializing the idea for a year. C-Lab guarantees autonomy in budgeting and scheduling, as well as in team formation. It is a flexible organization, wherein anyone can become a leader if they have ideas. A cumulative 297 projects 
were carried out through C-Lab, which involved 1194 executives and employees (as of July 2020). In other words, 35 to 40 projects are carried out every year. Initially, Samsung Electronics aimed to have more than 1\% (460) of its R\&D workforce participate in C-Lab by 2020. This was achieved three years earlier than planned, resulting in the propagation of a new way of working within the enterprise [43].

In addition, as the possibility of commercializing C-Lab ideas increased, Samsung Electronics introduced the corporate spin-off system in August 2015. Through this, 45 independent corporations were established, with a total of 163 employees participating in the venture (as of July 2020). These are examples of commercializing technologies based on C-Lab results. Samsung Electronics pushed for such a system with the intention that it is more important to directly examine consumer responses to products and services, communicate quickly, and be evaluated directly in the market. So far, the spin-off companies have accumulated \$47 million in investment, and their overall corporate value has more than tripled from the time of spin-off. In addition, this created more than 200 new jobs [42]. The study also measured the degree of entrepreneurial activity of the C-Lab spin-off entity for the global entrepreneurship monitor (GEM) measurement items presented by Niels and Donna [46]. As a result, the early-stage start-ups, younger than 42 months, constituted $44 \%$ of the total companies (of the 45 companies, 20 were spun-off after May 2017), the middle-aged start-ups, older than 42 months, constituted $53 \%$ (24 out of 25 companies were older than 42 months, excluding 1 company), those that closed down within 12 months constituted $0 \%$, and those involved in the fourth industry constituted 100\% (all 45 companies). Among the major spin-off companies are Linkflow, which became independent in November 2016 and achieved \$51 million in corporate value (as of July 2020), and Mangoslab, which achieved $\$ 7.7$ million in sales just a year after its founding.

\subsubsection{Development Process}

C-Lab, which is in its eighth year, is considered as a system that not only spreads the organizational culture of creativity and challenge within the company, but also makes disruptive innovation a reality. While selective concentration, strong leadership, and consistent organizational culture were the strengths of Samsung Electronics, it introduced C-Lab to internalize the spirit of challenge, creativity, and innovativeness, and facilitate rapid execution in the future [43].

Let us take a detailed look at how C-Lab has evolved and explore its key annual activities. This can be divided into five stages: (1) Securing a system for operation, (2) introduction of an online platform for CE activation, (3) expansion of a commercialization channel, (4) advancement of CE operation, and (5) creation of an external venturing program. The development process is summarized in Table 3.

Samsung Electronics first established a dedicated creativity-center to introduce and implement the corporate venturing system. The creativity-center concretely designed the system's implementation plans, such as recruitment and evaluation methods, compensation systems, and securing and executing of budgets. This is based on Drucker's (p. 150, [1]) argument that "entrepreneurial management requires specific practices pertaining to organizational structure, to staffing and managing, and to compensation, incentives, and rewards." For a corporate venturing system to be successful, the protection of the organization is important $[3,47]$. While the internal environmental factors found to affect corporate venturing include executive-level support and corporate strategies, organizational structures and processes, autonomous organizational culture, and compensation systems, the external environmental factors include technical opportunities and market demand for product and business models [6,48]. C-Lab actively accepted and institutionalized these environmental factors.

The most important feature of C-Lab is that autonomy is guaranteed, and failure is tolerated. Team formation, budget utilization, and schedule management are autonomous, and one can focus on the implementation of ideas in the holacracy. Since the participants are not held accountable for failure, they can challenge themselves for higher goals. Awards and incentives are provided if the project shows tangible results beyond its goal. In addition, the dedicated resources for C-Lab operation were secured from the head office, and a decision-making system consisting of five or more senior executives was established for the review and commercialization of ideas. These institutional frameworks are 
based on corporate venturing success factors, which were previously identified in a number of studies. These factors include executive-level support [49,50], separation from existing organizations $[3,51,52]$, and evaluation and compensation schemes [8,51,53-55].

Table 3. The development process of C-Lab and its major yearly activities.

\begin{tabular}{cl}
\hline Category & \multicolumn{1}{c}{ Major Activities } \\
\hline $\begin{array}{c}\text { 1st year } \\
(2013)\end{array}$ & $\begin{array}{l}\text { Organizational separation, securement of the framework for operating system, } \\
\text { establishment of the process of “discovery-implementation-commercialization of ideas” }\end{array}$ \\
\hline $\begin{array}{c}\text { 2nd year } \\
(2014)\end{array}$ & $\begin{array}{l}\text { Introduction of online collective intelligence platform (MOSAIC), } \\
\text { promotion of employees' participation }\end{array}$ \\
\hline $\begin{array}{c}\text { 3rd year } \\
(2015)\end{array}$ & $\begin{array}{l}\text { Strengthen the verification of idea marketability, } \\
\text { introduction and implementation of the corporate spin-off system }\end{array}$ \\
\hline $\begin{array}{c}\text { 4th-5th year } \\
(2016-2017)\end{array}$ & $\begin{array}{l}\text { Advancement of CE operation } \\
\text { (enhancement of incubation, constant discovering of ideas, expansion of operating base) }\end{array}$ \\
\hline $\begin{array}{c}\text { After the 6th year } \\
\text { (2018-) }\end{array}$ & $\begin{array}{l}\text { Joint operation of external venturing, establishment of the "C-Lab outside" program, } \\
\text { separate operation of “C-Lab inside" and “C-Lab outside" programs }\end{array}$ \\
\hline
\end{tabular}

Following this, the creativity-center laid the foundation for operation by addressing questions such as how to discover creative ideas, how to turn them into projects, how to operate them, and how to use the results after completion. C-Lab's process to develop ideas is largely divided into five stages, which are summarized in Table 4 . The first step is the idea discovery process, wherein ideas are suggested through a contest and participants get the opportunity to explain their concept. Once selected as a final C-Lab project, an idea moves through multiple stages, from team formation, budgeting, and mentoring to the implementation of the prototype. Once the implementation of the prototype is completed, each team will demonstrate the concept by presenting the development results at a corporate or global exhibition. In addition, successful exits will be promoted only for projects in which both the technical feasibility and market potential are confirmed. Table 4 draws a comparison between C-Lab's processes and the corporate venturing processes presented by Baek and Bae [47]. C-Lab not only included all the suggestions made by Baek and Bae [47], but also added more advanced and specific activities such as mentoring, demonstrating concepts, and deciding directions for commercialization.

In the second year after the introduction of the system, the company focused on promoting the participation of its executives and employees. Under the slogan "Thinking with your hands," it emphasized the importance of implementation and encouraged the participation of executives and employees. Introduced in March 2014, MOSAIC greatly contributed to the development of ideas. MOSAIC is a corporate online collective intelligence platform that connects people and develops ideas. MOSAIC became a decisive opportunity to discover creative talent and develop ideas that the company already possessed. Employees and executives in their 20s and 30s, who value voluntary participation and immersion, first began to show interest in collective intelligence activities; about 200 executives and employees participated in C-Lab every year.

In 2015, the use of C-Lab expanded not only within the company but also outside, as its business potential was confirmed, and its results received positive reviews from outside exhibitions. While achievements that are highly linked to the Samsung Electronics business are transferred to each of the business unit in the company to continue the follow-up development, when it is judged that there is a high possibility of commercialization from outside, the business is left independent as a startup to continue the business. This is a two-handed venture that combines internal and external enterprise activities. Gold [56] has proposed a similar form called the ACV-Model (Ambidextrous Corporate Venturing Model) as one of the way ideas are rotated in and out. 
Table 4. C-Lab's process of "discovering-implementing-commercializing of ideas".

\begin{tabular}{ccll}
\hline Stage & Content & \multicolumn{1}{c}{ Major Activities } & $\begin{array}{c}\text { Corporate Venturing Process } \\
\text { [47] }\end{array}$ \\
\hline 1 & $\begin{array}{c}\text { Finding } \\
\text { ideas }\end{array}$ & $\begin{array}{l}\text { An open audition-style ideas contest } \\
\text { Demo day, pitching day }\end{array}$ & $\begin{array}{l}\text { Problem-defining phase } \\
\text { (finding and evaluating ideas) }\end{array}$ \\
\hline 2 & $\begin{array}{c}\text { Project } \\
\text { planning }\end{array}$ & $\begin{array}{l}\text { Team forming (job posting) } \\
\text { Budget planning } \\
\text { Mentoring from technical and business experts }\end{array}$ & $\begin{array}{l}\text { Team environment } \\
\text { building phase }\end{array}$ \\
\hline 3 & $\begin{array}{c}\text { Prototype } \\
\text { implementation }\end{array}$ & $\begin{array}{l}\text { Verification of idea feasibility } \\
\text { (Apply Lean-Agile method) }\end{array}$ & Project execution phase \\
\hline 5 & $\begin{array}{l}\text { Proof of } \\
\text { concept }\end{array}$ & $\begin{array}{l}\text { Verification of idea marketability } \\
\text { (Corporate On-line and Offline C-Lab Fair, } \\
\text { submission for global exhibition) }\end{array}$ & $\begin{array}{l}\text { Deciding the direction for commercializing ideas } \\
\text { (corporate spin-off or transfer to the business units } \\
\text { in Samsung) }\end{array}$ \\
\hline 5
\end{tabular}

After that, in 2016, C-Lab promoted the advanced operation. More than anything, it strengthened its incubation capacities. A dedicated organization was formed with related experts, who were responsible for promoting the commercialization of completed projects and managing the support of spin-off companies. In addition, it created a dedicated space in Suwon and Seoul, Korea, where Samsung's HQs is located, and increased the efficiency by distributing projects. Furthermore, the idea was always suggested under the slogan "Ideas have expiration dates." In 2017, C-Lab expanded its foothold to Samsung Electronics-Seoul National University Joint Research Center located within the university in Korea.

In 2018, C-Lab expanded its scope of operation and support outside the company under the name "C-Lab Outside." "C-Lab Outside" is an outside venturing program that supports and fosters external start-ups based on C-Lab's accumulated know-how in operation. Since its launch, the existing corporate venturing system has been operating separately as "C-Lab Inside." Thus, C-Lab includes the academic concepts of inside as well as outside corporate venturing [13,57].

As such, C-Lab, Samsung Electronics' corporate venture, has been active since December 2012. Through the corporate venture system, Samsung Electronics discovers and fosters creative talent and ingenious ideas, and through this, it pursues sustainable growth of companies and seeks the spread of creative organizational culture.

\subsection{CE of C-Lab Spin-off Company}

\subsubsection{Company A}

Choi, the founder of company A, is a former member of Samsung Software Membership, a program that supports R\&D for college students with software skills. He served as a member for six years, since his second year at the university. He showed incredible confidence in the implementation of technology and proposed and implemented 11 ideas over six years. During his time there, he focused on implementing ideas with the goal of resolving people's inconvenience with technology.

He applied to C-Lab to develop the technology to transmit sound through the human body. He focused on the development for six months and then produced the prototypes, which were submitted to the C-Lab Fair, a corporate exhibition at Samsung Electronics. However, the feedback from colleagues contrasted with what he had expected. Choi says the following.

"The executives and employees who used the product praised the product's innovativeness, but said they would not actually use it. The reason was that the electric signal has an effect on the body as it passes through. I was shocked. But I realized that innovation and the good technology that 
consumers need are different things, and I struggled with it again. I quickly changed directions during the two months and introduced a new technique, and this was the decisive move."

The smart band, developed in a year, was chosen as the best C-Lab task, and as a result Choi got a chance to spin-off. To Choi's fortune, Samsung Electronics' top executive supported his spin-off decisively. Cho says the following.

"Many of the new technologies and creative ideas that are developed every year in Samsung don't fit in with Samsung's business group and are discarded, and the top executive felt sorry for this. So, he said that he would like to give a chance to brilliant ideas and to those who are most attached to them. And he said that if we grow up strong in the start-up ecosystem for 5 to 10 years, we will become a strong partner for Samsung Electronics. Therefore, the corporate spin-off system should continue" [42].

He dreamed of starting a business before joining the company and got a chance to start a business at the age of 33 through the C-Lab spin-off system.

“Unlike software-based services, technology-based startups require significant upfront funding. It takes more than a year to develop the product, and it takes a lot of investment to mass-produce the product. We were lucky to be able to prototype it with C-Lab, and we also had the opportunity to create a business with the corporate spin-off system. In addition, we were able to secure key talents and excellent processes based on our experience with Samsung Electronics. I think entrepreneurship is not about creating a new business ecosystem, it's about capturing opportunities and implementing them." Choi says that.

Company A is a hardware startup that develops new concept wearable devices. It introduced its products on the American crowdfunding platform, Kickstarter, a year after its foundation. In just 45 days, it successfully raised $\$ 1.47$ million, drawing global attention. The fund-raising amount was 30 times the target amount, making to the top $0.003 \%$ of the Kickstarter record. However, over the next two years, Company A had a hard time. The production of 15,000 orders did not go as scheduled, leading to complaints from consumers due to delayed delivery and poor function of products. Nevertheless, Company A overcame the crisis by actively responding to A/S. It successfully improved its products and updated the related software.

\subsubsection{Company B}

It was largely because of his father's influence that the founder of Company B, Cho, decided to start a business. After careful consideration, he decided to spin-off because he grew up seeing his father challenging himself all over the world for his business. "Health information, location information, and various data in our daily lives come from our feet. Most wearable devices, on the other hand, are concentrated in the upper part of the body. We're sure that 'smart shoes' will open a new world. And the challenge to the blue ocean market is an advantage for people from C-Lab." Cho says that. This is the background of Company B's establishment and the driving force for its growth.

Company B's internalized technology through C-Lab is a solution that accurately measures and analyzes body balance. This solution began with the correction of incorrect gait and posture, and its application extended to fitness and golf. Information on body balance is important, which is directly related to health, and can be applied to various sports. As a result, Company B won the Innovation Award at CES, the world's largest electronics exhibition, in 2017, and is currently growing by forming strategic alliances with more than 400 fitness centers and rehabilitation centers.

According to a survey by the KISED [58], it takes an average 36.4 months for a normal venture company to generate sales after its start-up. The biggest difficulties before achieving sales are financing $(58 \%)$, marketing issues $(17 \%)$, manpower supply $(5 \%)$, lack of technology $(5 \%)$, and others $(15 \%)$. The probability 
of start-up companies surviving for 10 years is only $17.5 \%$. However, the investment and support of the initial parent company contributes greatly to the performance and survival of the spin-off companies.

Cho makes the following statement with respect to Company B's growth factors and corporate vision: "It was possible because it started as a corporate venture. Although I was anxious to think about survival and growth when I left a stable conglomerate, the C-Lab spin-off system has supported not only technical skills but also management, legal advice, and networking. I think corporate spin-off is an opportunity to realize innovative value and an opportunity to explore the future. The key value we want to deliver to our customers is to live a healthy, enjoyable, and long life. That's what we want to do for society."

Cho stressed that innovation is a challenge to what is invisible and a power to seize opportunities. "The beginning of innovation is action and perseverance. There are many opportunities around you that inspire innovation, including institutional support for businesses, national policies, and market and industry changes. It's innovation that captures these opportunities, creates products and services, and creates market value based on them, and the criteria for opportunity capture is 'Why now?'." Finally, he says, "C-Lab is a system of raising people, and corporate spin-off is a system for developing combat power DNA to survive in the market."

\subsubsection{Company C}

Founded in 2016, Company C won the top innovation award at CES in 2017, six months after its spin-off. It achieved sales of $\$ 7.7$ million in just one year after its foundation. In 2019, the company was selected as a "high-growth software company" by the Ministry of Science and ICT in Korea, winning a competition ratio of 9 to 1 .

The year 2014 marks the starting point of Company C. The members who initially proposed the idea to C-Lab quit Samsung Electronics earlier, and four others, including CEO Jeong, who were attracted to the idea, joined the commercialization. When asked what the best thing after the spin-off was, Jeong replied, "The best thing was to get a chance to focus only on fun things and things that we're good at."

On the benefits of the corporate spin-off system, Jeong said, "In the early stages of the start-up, the founder's management ability is very important, such as securing core resources and differentiating business models. We started with four people and within 2 years of our foundation, the number of employees increased to 23, and there are three more from Samsung Electronics among the additional employees. Whenever we desperately needed talent, the parent company network has been a big help. I've been working at Samsung Electronics for nearly 10 years, in charge of developing mobile phone software and planning new businesses and new products, and this experience has helped me a lot in my management."

In fact, an important growth factor in the early stages of a start-up is the entrepreneur leading resources and organizations; start-ups can generate results through the founders' capabilities [59-61].

Company $\mathrm{C}$, which combines the advantages of analog and digital in its products, believed that it could draw great productivity from small changes that do not undermine the user experience. In 2017 and 2020, it released two products, and smoothly completed the supply of hundreds of thousands of products. Ironically, however, the two previous product launches came as two significant crises for Company C. It faced practical difficulties such as negotiating with large companies and economies of scale. However, looking back, Jeong believes that he was able to grow from each of the crises. In order to stick to its essence, Company $\mathrm{C}$ is now focusing on making products the market and customers like. Jeong stresses that focusing on the market is the success factor of entrepreneurial management.

At the end of the interview, Jeong quoted Andreessen [4], pointing out the two stereotypes around entrepreneurship. "People often think entrepreneurs are very creative. However, there are many types of creativity required for management. First, openness and curiosity about new experiences are more important than brilliant ideas. Second, entrepreneurs enjoy risk taking. Entrepreneurs also want to minimize risk in all opportunities. But a true entrepreneur is willing to accept risk rather than enjoy it." 


\subsubsection{Company D}

Company D's flagship product is a neckband-type 360-degree camera. Its strengths are the option of operating it hands free, filming from a first person's point of view, and facilitating 360-degree video-based real-time communication. The founder's previous experience is closely related to the conception of the idea and willingness to start the business, which led to the pursuit of opportunities [62]. CEO Kim of Company D came up with the idea after his honeymoon in 2007. "I thought I needed a device to record someone's experience and convey the emotion from that time. Unfortunately, however, as Samsung Electronics was wrapping up its camera business at the time, Kim sought to realize his conviction. He later won the grand prize at the 2014 Samsung Electronics new business idea contest with this idea, and after going through the C-Lab incubating process, he went on to create Company D in 2016.

The wearable form and first-person perspective solution have a big difference from other products in terms of usability and quality of video. In the early stages, a form factor in the shape of glasses was considered, however, it was changed later to a neckband, considering the usability such as shaking of the video, fever, and convenience. In addition, the business did not limit itself to just B2C devices for experience recording, it also released third-generation models with more focus on the security solution market for B2B. As the product evolved from first- to third-generation, it is the voice of the field that he considered the most. On-site surveys were conducted several times before product development began, and actual feedback such as light weighting, camera separation, and battery separation were reflected. It is said that the direction of a product must be determined by the following three criteria: (1) Is it a product that customers need? (2) Is it worth the cost? (3) Is it a problem that we can solve? [63]

When it comes to know-how about B2B market strategy, Kim says, "Be prepared to seize time and opportunity." In fact, Company D has recently suffered an unexpected blow from COVID-19 and has gained unexpected opportunities. Initially, he was preparing to submit to MWC, the world's largest telecommunications exhibition, but it was canceled owing to the concerns over the spread of COVID-19. However, post the crisis, another opportunity arose. In order to remotely treat patients in Wuhan, China, during COVID-19, a large-scale order request was received from China. Technology-based start-ups can survive the initial few years because the potential possibilities have a great ripple effect when they meet the market demand [64]. In fact, Company D had almost no sales during the first two years. Although it started selling products in 2018, it made only $\$ 180,000$ in annual sales, and only $\$ 1.3$ million in sales in 2019. However, as untact demand increased due to the impact of COVID-19. Company D received orders of over $\$ 25$ million value in the first half of 2020 alone.

The accumulated investment in Company D amounts to $\$ 19$ million and its corporate value stands at $\$ 51$ million (as of July 2020). When asked if there were any difficulties in raising funds, Kim said, "In the early days of corporate IR, we were rejected all the time. But each time I strengthened my resolve, saying 'Just wait and see! I'll make it no matter what!' Eventually, I succeeded in attracting investment on my 14th attempt. As such, we are moving forward by repeating challenges and failures. But would I have thought of this without the corporate spin-off system? In that sense, the corporate spin-off system is a once-in-a-lifetime opportunity for someone [42]."

In addition, Company D won the CES Innovation Award for three consecutive years from 2018, and the numbers of employees have increased from 4 to 40 . As for the growth factors, Kim internally mentioned the pride of executives and employees. In addition, he pointed out externally that business and government support, growth of related technologies such as $5 \mathrm{G}$ and VR, and social trends. He also emphasized the ability to push ahead quickly when the opportunity comes.

\subsubsection{CE Comparison of Case Study Companies}

As described above, this research studies, in-depth, not only the corporate venturing activities of $\mathrm{C}$-Lab, but also the growth processes and performances of spin-off companies. We were able to see through specific examples how CE works in crisis situations and how the environmental factors affect performances. A summary of this is given in Table 5. CE originates from entrepreneurial characteristics such as creative ideas, a challenging spirit, and execution power, leading to entrepreneurial 
activities including crisis management and seizing of opportunities. Employees can demonstrate entrepreneurship through corporate venturing opportunities and can generate practical results that go beyond organizational boundaries via spin-off opportunities. In the process, corporate venturing and corporate spin-off systems have become an opportunity to directly face the world and read its trends. Innovation occurs in the process of turning ideas into business opportunities and realizing opportunities ahead of others.

Opportunities are very important for entrepreneurs. The interaction of entrepreneurial characteristics and opportunities is a key research area that can develop entrepreneurship into an independent field of management [35]. From an academic point of view, opportunity means a situation in which there is potential to dominate the market with new products and services [65], and innovation can occur in the process of turning ideas into opportunities and realizing opportunities ahead of others. The documents analysis and interviews show that the word mentioned most frequently and repeatedly was "opportunity." Through corporate venturing and corporate spin-offs, the representatives of spin-off companies say that they have gained the opportunity to implement ideas, the opportunity to experiment with ideas, the opportunity to focus, the opportunity of a lifetime, the opportunity to make dreams come true, the opportunity to create business, and the opportunity to pioneer the market and future. These opportunities can lead to financial and non-financial performances in the short term and serve as a cornerstone for realizing innovative value in the mid- to long-term. In other words, the implementation of the corporate spin-off system means whether CE is limited within the company or extended to the outside world. Since the external expansion of CE means a point of contact with the market, the corporate spin-off system is an opportunity for innovation with great potential and impact.

Table 5. Corporate entrepreneurship (CE) of case study companies.

\begin{tabular}{|c|c|c|c|c|}
\hline & Company A & Company B & Company C & Company D \\
\hline Business area & Novel concept wearable device & Smart shoes solution & $\begin{array}{c}\text { Adhesive } \\
\text { memo printer }\end{array}$ & Wearable 360-degree camera \\
\hline $\begin{array}{l}\text { Entrepreneur-ial } \\
\text { characteristics }\end{array}$ & $\begin{array}{l}\text { - Implemented } 11 \text { ideas in college } \\
\text { - Planned a start-up at age } 35 \\
\text { before joining the company }\end{array}$ & $\begin{array}{l}\text { Influenced by businessman } \\
\text { father, decided to start the } \\
\text { business }\end{array}$ & $\begin{array}{l}10 \text { years of work experience } \\
\text { in Samsung was helpful in } \\
\text { management }\end{array}$ & $\begin{array}{l}\text { - Feeling the need for the } \\
\text { device during honeymoon, } \\
\text { - Start implementing ideas } \\
\text { himself }\end{array}$ \\
\hline $\begin{array}{l}\text { Entrepreneur-ial } \\
\text { activity } \\
\text { (crisis } \\
\text { management) }\end{array}$ & $\begin{array}{l}\text { - Developed "technology to } \\
\text { deliver sound through human } \\
\text { body" at C-Lab } \\
\text { - Received negative feedback from } \\
\text { colleagues about the marketability } \\
\text { - Introduced a breakthrough } \\
\text { technology in } 2 \text { months }\end{array}$ & $\begin{array}{l}\text { The initial goal was to correct } \\
\text { walking styles and postures, } \\
\text { However, it was difficult to } \\
\text { generate continuous profit } \\
\text { - Expansion of business to } \\
\text { fitness and golf }\end{array}$ & $\begin{array}{l}\text { - Released two products and } \\
\text { supplied hundreds of } \\
\text { thousands of items in } 2017 \\
\text { and } 2020 \\
\text { - Due to the lack of bargaining } \\
\text { power with large enterprises } \\
\text { and economy of scale, } \\
\text { histories of two product } \\
\text { launches acted as two crises }\end{array}$ & $\begin{array}{l}\text { - Not easy to secure wearable } \\
\text { usability by solving device } \\
\text { problems such as image } \\
\text { shaking and heating } \\
\text { - While investment in HW } \\
\text { development was large, the } \\
\text { sales were low for } 3 \text { years } \\
\text { after start-up }\end{array}$ \\
\hline $\begin{array}{l}\text { Environmental } \\
\text { factors }\end{array}$ & $\begin{array}{l}\text { - Development of related } \\
\text { technology }\end{array}$ & - National policy & $\begin{array}{l}\text { - Strategic cooperation } \\
\text { between companies }\end{array}$ & $\begin{array}{l}\text { Untact demand due to } \\
\text { COVID-19 } \\
\text { - Development of related } \\
\text { technology }\end{array}$ \\
\hline Performance & $\begin{array}{l}\text { Raised } \$ 1.47 \text { million at } \\
\text { Kickstarter (receiving funds } 30 \\
\text { times more than the target, record } \\
\text { for being in the top } 0.003 \% \text { of } \\
\text { companies) }\end{array}$ & $\begin{array}{l}\text { - Innovation Award } \\
\text { at CES } 2017 \\
\text { - Strategic alliances with } 400 \\
\text { fitness and rehabilitation centers }\end{array}$ & $\begin{array}{l}\text { Sales of } \$ 7.7 \text { million } \\
\text { in just } 1 \text { year since its } \\
\text { foundation } \\
\text { - Top Innovation Award CES } \\
2017 \\
\text { - Selected as Korea's "High } \\
\text { Growth SW Company" }\end{array}$ & $\begin{array}{l}\cdot \$ 19 \text { million } \\
\text { in accumulated investment } \\
\cdot \$ 51 \text { million } \\
\text { in corporate value } \\
\text { (as of July 2020) } \\
\text { - Innovation Award CES } \\
2018-2020\end{array}$ \\
\hline
\end{tabular}




\subsection{The Evolutionary Model of CE}

Based on the CE growth factors and performances derived from C-Lab case studies, this study proposes an evolutionary model of CE. Here "evolution" means the expansion and development of the scope of research from the individual-level to the firm-level, and from the firm-level to the social- level. The evolutionary model of CE proposed in this study is shown in Figure 2.

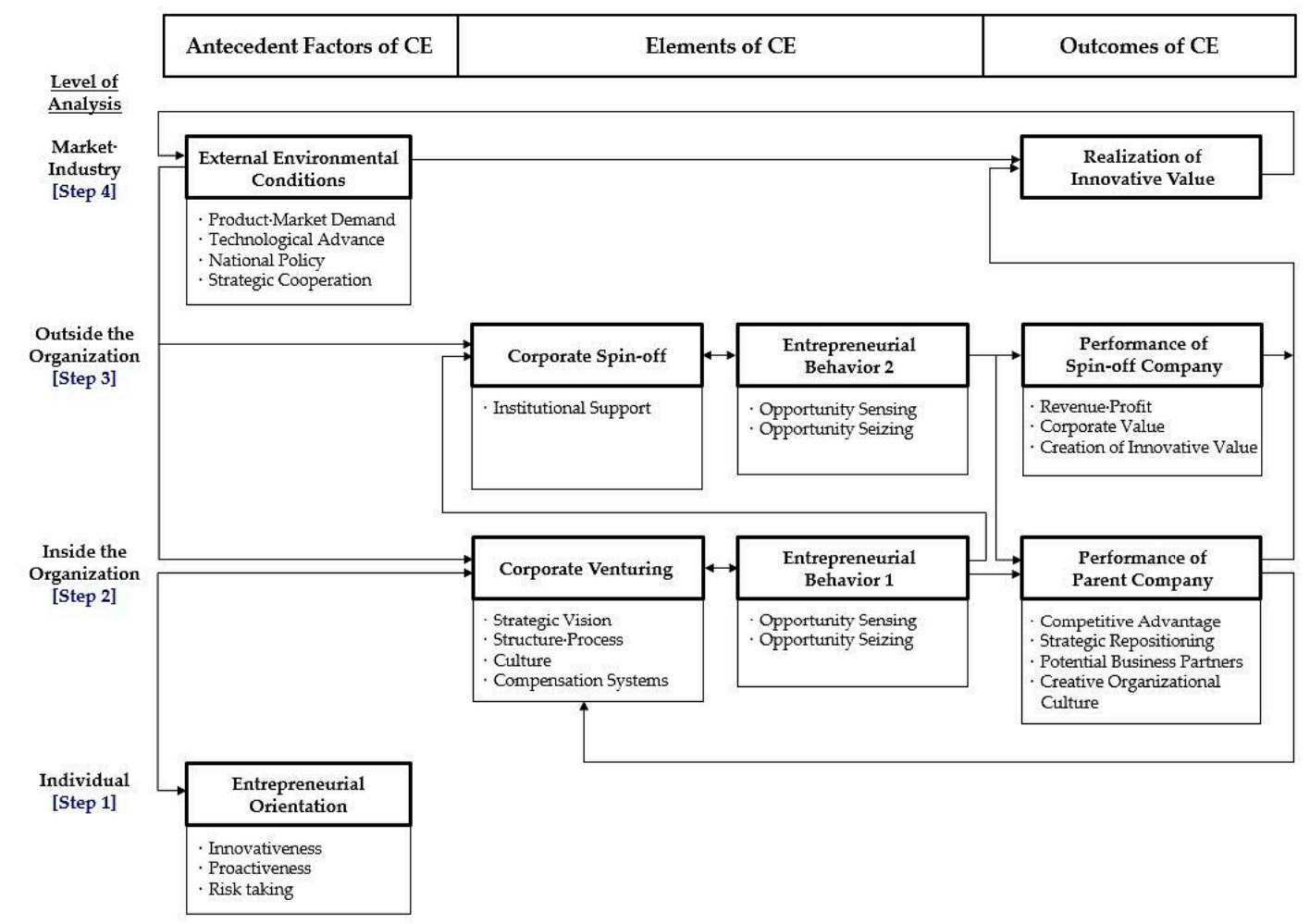

Figure 2. The evolutionary model of CE.

To build the model, the 22 keywords finally derived based on document analysis and interviews were divided into four levels: "Individual," "Inside the Organization," "Outside the Organization," and "Market and Industry." This is according to the research model in Figure 1. Then, they were further subdivided into nine categories. The nine categories are "Entrepreneurial Orientation," "Corporate Venturing," "Entrepreneurial Behavior of Corporate Venturing," "Performance of Parent Company," "Corporate Spin-off," "Entrepreneurial Behavior of spin-off'," "Performance of Spin-off Company," "External Environmental Conditions," and "Realization of Innovation Value." The model was then completed by dividing the 3 categories into "Antecedents," "Elements," and "Outcomes of CE." For example, the initial keyword "Challenging Spirit" is reduced to the keyword "Proactiveness" (minor category), and this belongs to the category "Entrepreneurial Orientation" at the individual-level (middle category), and this in turn corresponds to "Antecedent of CE" (major category).

$\mathrm{CE}$ can evolve following the stages [Step 1] to [Step 4] in Figure 2.

[Step 1] Individual

$\mathrm{CE}$ comes from the entrepreneurial orientation of each member of an organization. Entrepreneurial orientation is defined as innovativeness, proactiveness, and risk taking, in accordance with the representative concepts of the theory [15]. However, it also includes overall entrepreneurial beliefs, attitudes, and values. Individuals' entrepreneurial orientation is developed into collective intelligence via institutions and systems of the company and can be expressed in terms of firm-level entrepreneurial behavior. 


\section{[Step 2] Inside the Organization}

This step includes the elements and outcomes of CE. Corporate venturing and entrepreneurial behavior 1 are the most important components of this model. Corporate venturing includes the strategic vision of the company, organizational structure and processes, autonomous organizational culture, and compensation system, as identified in a prior study [6]; the support of the chief executive is part of the strategic vision.

Corporate venturing is influenced by entrepreneurial orientation and external environmental factors. In particular, external environmental factors such as product and market demand, technological advance, and national policy have a direct impact on the level of support from the chief executive. Ireland et al. [5] says that support from chief executive is an important part of CE success, and that corporate venturing is an organizational means to promote harmony between support from the chief executive and entrepreneurial behavior 1 . Thus, corporate venturing is a decisive factor in encouraging entrepreneurial behavior 1. Furthermore, it is the most important and most difficult process as it includes both the organizational structure, which is a hardware characteristic, and the organizational culture, which is a software characteristic [5].

Entrepreneurial behavior 1 involves entrepreneurial efforts such as sensing and seizing opportunities, and the interaction between corporate venturing and entrepreneurial behavior 1 eventually constitutes the performance of the parent company. The performance of a parent company includes securing competitive advantage for sustainable growth, strategic repositioning as an innovative company, and the spread of an organizational culture of creativity and challenge, which were derived as constituting the performance of the parent company from the C-Lab case study. In addition, the performance of the parent company eventually leads back toward the support for the corporate venturing system, creating a virtuous cycle. In addition, the institutional and cultural characteristics of corporate venturing have a positive effect on stimulating and activating the entrepreneurial orientation of the members of the organization.

\section{[Step 3] Outside the Organization}

Like the research model in Figure 1 and the results of the C-Lab case study, the unique feature of this study is that the range of CE was expanded to corporate spin-off. Thus, this model added corporate spin-off as an element of $\mathrm{CE}$ and an activation factor. Corporate spin-offs include institutional support from the parent company, such as separation and independence of the workforce, equity investment, granting the right to use patents, and management support.

In addition, as seen in the CE activities of C-Lab spin-off companies in Section 4.2, the process of sensing and seizing various opportunities through start-ups leads to actual results, including revenue and profit, improvement in corporate value, and creation of innovative value. Further, there are achievements such as job creation and investment attraction. Also, courtesy of the entrepreneurial activities of spin-off companies, the parent company can secure potential business partners and establish a sustainable cooperative system.

\section{[Step 4] Market Industry}

This step includes the antecedents and expected outcomes of CE. As the C-Lab spin-off companies have experienced, CE's performance is maximized when the performance of spin-off companies meets the product and market demands, the advancement of related technologies, and national policies. In particular, national policies have a positive impact on corporate financing and the business environment [66]. Further, the performance of spin-off companies is a source of innovation. If the innovative value created by performance is widely popularized and distributed through strategic cooperation between companies, CE can surpass the financial and non-financial performance of the firm-level. Also, it is expected to lead toward the realization of innovative value at the social level.

The mid- to long-term performance of $\mathrm{CE}$ will again have a positive impact on the changes in the market and industrial environment, and the changed external environment will also have a positive 
impact on CE activities inside and outside the organization. It is expected that this causal virtuous circle will ultimately have a positive impact on the sustainable growth of the enterprise.

\section{Discussion}

As shown above, $\mathrm{CE}$ activities promote sensing and seizing of opportunities via corporate venturing and corporate spin-offs. CE activities, both inside and outside the organization, also provide a strategic advantage, which is not fully captured by financial performance [6]. With regard to strategic repositioning, for example, the parent company can place a product in a new position within a market area and may change the properties of that area. Securing competitive advantage may in turn have a direct impact on CE strategies via corporate venturing.

This model divides each component into "Antecedents," "Elements," and "Outcomes" of CE, and breaks down the analytical units into levels like the structure of the CE strategy model presented by Ireland et al. [5]. When the keywords derived from the C-Lab case study were compared with the model presented by Ireland et al. [5], the components of [Step 1]-[Step 2] and their connections matched significantly. However, as this study expanded the CE scope to corporate spin-off, [Step 3]-[Step 4] were created for outside the organization. Therefore, this study proposes an evolutionary model of $C E$ from the viewpoint of more active $C E$ activities.

There are prior studies that show that CE works more flexibly in small and medium-sized enterprises than in large enterprises [17]. The reason for this would have to be the bureaucratic systems of large corporations; the various management and monitoring systems of big corporations hinder the autonomy and creativity required for CE. However, one can apply Drucker's (p. 148, [1]) view to the study that "It is not true that bigness is an obstacle to entrepreneurship and innovation. In discussions of entrepreneurship one hears a great deal about the bureaucracy of big organizations and of their conservatism. And the existing seems to be even more of an obstacle." Samsung C-Lab is a new system for fundamental innovations such as working methods and business paradigms, and the independence and autonomy are guaranteed under organizational support. In addition, the decisive trigger for Samsung to promote the corporate spin-off was the concerns around the NIH syndrome, an exclusive attitude within the organization. Nevertheless, it is also necessary to take into consideration the negative effects of $C E$ raised by some of the studies. The positive effects of $C E$ reported so far may be overestimated [9] due to the errors in the survivorship bias of the sample. It was also noted that $\mathrm{CE}$ is an experimental activity for seizing opportunities and does not necessarily guarantee success [67]. This means that a proper management is needed to avoid excessive emphasis on CE and ensure that positive benefits work more strongly than the negative effects. In addition, efficient management of resources must be the first activity to improve the effectiveness of CE strategy.

The importance and virtuous cycle of $\mathrm{CE}$ can also be interpreted in terms of sustainability. More and more organizations around the world are recognizing their role in sustainability. The "Sustainable development" means development that meets current needs without compromising the ability of future generations to meet their own needs. It plays an important role not only in economic and social development, but also in business [68]. In addition, the relationship between CE and sustainable development turns strongly positive in the presence of high levels of innovation and institutional quality [69]. Corporate practices for sustainability provide better ways to manage human resources, which ultimately leads to improved productivity and long-term business success. In the end, it contributes to a stable society [68]. An important point here is that market innovation that drives sustainability does not happen by accident. It must be created. Corporate should develop new products and services that improve their quality of life, and CE is a core value for this [70].

It is also possible to extrapolate the importance of creativity in terms of sustainability. Innovation, an entrepreneurial characteristic of individuals and companies, is the process of turning creative and market-oriented ideas into opportunities [22]. Creativity is important because it provides new solutions that go beyond existing limits [71]. Therefore, creative ideas and the institutional environment supporting them lead the growth and development of companies. 
Finally, corporate ventures and corporate spin-off systems are good evidence of the importance and strength of CE. In particular, as shown in Figure 2, the parent company's institutional support for the corporate spin-off is eventually returned to the parent company's performance, such as securing potential business partners. Focusing on this point of view, the interpretation of the corporate spin-off system in the concept of the "sharing economy" will be a useful direction for future research. Given that the sharing economy creates new opportunities for value creation and innovation [72], the corporate spin-off system can be an alternative for corporate to participate in the sharing economy.

\section{Conclusions}

We conducted a case study on Samsung C-Lab to propose the evolutionary model of CE including corporate ventures and corporate spin-off systems in terms of entrepreneurial activities. The academic significance of this study is as follows.

First, while previous studies on CE measured growth factors and performance primarily from an entrepreneurial orientation perspective or limited to corporate activities, this study expanded its scope to corporate spin-offs. This allowed us to look at another level of growth and opportunity that exists beyond the boundaries of an organization. The study also presented specific implementation methods and evolutionary models, which exceed the limitations raised in prior research.

Second, this study can enable organic connection and comprehensive interpretation between entrepreneurial orientation, $\mathrm{CE}$, corporate venturing, and corporate spin-offs. This allows a new assessment of the relationship between $\mathrm{CE}$ and performance and can contribute toward building an evolution mechanism of CE. Further accumulation of such findings could contribute to academic measurement and diagnosis of a company's CE level.

Third, the study contributes toward further solidifying the foundation of technology management theory by mapping and analyzing the opinions of existing scholars on $\mathrm{CE}$, with cases reflecting the situation of the times. The study confirms that a number of theories from the 1980s on entrepreneurship, including those of Drucker [1] and Miller [15], are still applicable 40 years later.

The study has important implications in practice. For companies that are hesitant to introduce the corporate venture system, the effect is presented in advance. In addition, specific operational plans and practical benefits are presented for companies that are contemplating the systematic introduction of the corporate venture system. According to Kuratko et al. [7], all the challenges and frustrations a company faces when introducing and activating CE are important research topics.

Innovation is about making. Innovation that has never existed stems from the process of entrepreneurial orientation, entrepreneurial activity, and seizing of opportunities. Further efforts are needed to link CE to the realization of innovative value. If environmental factors such as product market demand, technological advance, national policy, and strategic cooperation are added beyond the firm-level, CE can have a greater impact on the future than the achievements that have been visible so far at the social-level.

Despite its academic and practical significance, this study contains essential limitations. Thus, relevant research should continue while also supplementing the following.

First is the expansion of the research subject. It would be more effective to generalize the findings if the case study included has a large number of global companies, rather than confining the case study to a single company. In subsequent studies, it would be more meaningful to diversify the cases on the basis of country and industry and compare their characteristics.

Second is the expansion of research methods. It is necessary to further strengthen the reliability and validity of the findings by adding empirical studies on the basis of this case study. The use of statistical analysis methods for verification may provide more abundant research results.

Third is the expansion of the research scope. Of all the C-Lab projects, this study focuses on the corporate spin-off cases. However, by analyzing the existing status of the C-Lab projects as a whole, including in-house transfer cases and failure cases, one can produce meaningful research results. 
Fourth is the extension of the research period. Finally, the follow-up study that the researcher is most interested in is a longitudinal study of C-Lab spin-off performance. Although this study is a cross-sectional study, a longitudinal study of spin-off companies will have great academic and practical significance.

$\mathrm{CE}$ and corporate venturing can create a variety of research tasks as they combine with the phenomena of the times. It is also expected that the actual importance and impact of these will be further expanded. Thus, the accumulation of experience and knowledge in the field is more necessary than anything else.

Author Contributions: Conceptualization, B.Y.S.; methodology, B.Y.S. and K.T.C.; software, B.Y.S.; validation, B.Y.S. and K.T.C.; formal analysis, B.Y.S.; investigation, B.Y.S.; data curation, B.Y.S.; writing-original draft preparation, B.Y.S.; writing-review and editing, B.Y.S. and K.T.C.; supervision, K.T.C. All authors have read and agreed to the published version of the manuscript.

Funding: This research received no external funding.

Conflicts of Interest: The authors declare no conflict of interest.

\section{References}

1. Drucker, P.F. Innovation and Entrepreneurship; Harper and Row: New York, NY, USA, 1985. Available online: https://www.pdfdrive.com/drucker-1985-innovation-and-e-d29476399.html (accessed on 22 September 2020).

2. Schumpeter, J.A. Capitalism, Socialism, and Democracy; Harper and Brothers: New York, NY, USA, 1942.

3. Gartner, W.B. A conceptual framework for describing the phenomenon of new venture creation. Acad. Manag. Rev. 1985, 10, 696-706. [CrossRef]

4. Blank, S.; Andreessen, M.; Hoffman, R.; Sahlman, W.A. HBR's 10 Must Reads on Entrepreneurship and Startups; HBR Press: Boston, MA, USA, 2019; pp. 1-159. Available online: https://moodle2.units.it/pluginfile.php/ 287259/mod_resource/content/1/HBR_readings_underlined.pdf (accessed on 22 September 2020).

5. Ireland, R.D.; Covin, J.G.; Kuratko, D.F. Conceptualizing corporate entrepreneurship strategy. Entrep. Theory Pract. 2009, 33, 19-46. [CrossRef]

6. Narayanan, V.; Yang, Y.; Zahra, S.A. Corporate venturing and value creation: A review and proposed framework. Res. Policy 2009, 38, 58-76. [CrossRef]

7. Kuratko, D.F.; Hornsby, J.S.; Hayton, J. Corporate entrepreneurship: The innovative challenge for a new global economic reality. Small Bus. Econ. 2015, 45, 245-253. [CrossRef]

8. Hill, S.A.; Georgoulas, S. Internal Corporate Venturing: A Review of Five-Decades of Literature; Handbook of Research on Corporate Entrepreneurship, Edward Elgar: Cheltenham, UK, 2016; pp. 13-63. Available online: https:/www.elgaronline.com/view/edcoll/9781785368721/9781785368721.00007. xml (accessed on 22 September 2020). [CrossRef]

9. Lee, J.Y.; Park, T.K. The nonlinear relationship between corporate entrepreneurship and performance: The moderating effect of absorptive capacity. J. Bus. Res. 2017, 32, 147-175.

10. Bae, J.T.; Cha, M.S. Recent trend in entrepreneurship and venture management research: A comparative analysis of Korean and American journals (1998-2004). J. Small Bus. Innov. 2005, 8, 57-94.

11. Kuratko, D.F.; Audretsch, D.B. Clarifying the domains of corporate entrepreneurship. Int. Entrep. Manag. J. 2013, 9, 323-335. [CrossRef]

12. Abadli, R.; Kooli, C.; Otmani, A. Entrepreneurial culture and promotion of exporting in Algerian SMEs: Perception, reality and challenges. Int. J. Entrepreneurship Small Bus. 2020, 41, 227-240. [CrossRef]

13. Sharma, P.; Chrisman, J.J. Toward a reconciliation of the definitional issues in the field of corporate entrepreneurship. Entrep. Theory Pr. 1999, 23, 11-28. [CrossRef]

14. Dess, G.G.; Ireland, R.D.; Zahra, S.A.; Floyd, S.W.; Janney, J.J.; Lane, P.J. Emerging issues in corporate entrepreneurship. J. Manage. 2003, 29, 351-378. [CrossRef]

15. Miller, D. The Correlates of entrepreneurship in three types of firms. Manag. Sci. 1983, 29, 770-791. [CrossRef]

16. Covin, J.G.; Slevin, D.P. Strategic management of small firms in hostile and benign environments. Strat. Manag. J. 1989, 10, 75-87. [CrossRef]

17. Lumpkin, G.T.; Dess, G.G. Clarifying the entrepreneurial orientation construct and linking It to performance. Acad. Manag. Rev. 1996, 21, 135-172. [CrossRef]

18. Guth, W.D.; Ginsberg, A. Guest editors' introduction: Corporate entrepreneurship. Strateg. Manag. J. 1990, $11,5-15$. 
19. Zahra, S.A. Environment, corporate entrepreneurship, and financial performance: A taxonomic approach. J. Bus. Ventur. 1993, 8, 319-340. [CrossRef]

20. Zahra, S.A. Goverance, ownership, and corporate entrepreneurship: The moderating impact of industry technological opportunities. Acad. Manag. J. 1996, 39, 1713-1735. [CrossRef]

21. Burgelman, R.A. A Process model of internal corporate venturing in the diversified major firm. Adm. Sci. $Q$. 1983, 28, 223. [CrossRef]

22. Covin, J.G.; Lumpkin, G.T. Entrepreneurial orientation theory and research: Reflections on a needed construct. Entrep. Theory Pr. 2011, 35, 855-872. [CrossRef]

23. Burgers, J.H.; Covin, J.G. The contingent effects of differentiation and integration on corporate entrepreneurship. Strat. Manag. J. 2016, 37, 521-540. [CrossRef]

24. Tang, J.; Tang, Z.; Marino, L.D.; Zhang, Y.; Li, Q. Exploring an inverted u-shape relationship between entrepreneurial orientation and performance in Chinese ventures. Entrep. Theory Pr. 2007, 32, $219-239$. [CrossRef]

25. Roberts, E.B. New ventures for corporate growth. HBR 1980, 58, 134-142. Available online: https: //hbr.org/1980/07/new-ventures-for-corporate-growth (accessed on 22 September 2020).

26. Dollinger, M.J. Entrepreneurship: Strategies and Resource, 4th ed.; Marsh Publications: Lombard, IL, USA, 1995; pp. 1-601.

27. Campbell, B.A.; Kryscynski, D.; Olson, D.M. Bridging Strategic Human Capital And Employee Entrepreneurship Research: A labor market frictions approach. Strat. Entrep. J. 2017, 11, 344-356. [CrossRef]

28. Biggadike, R. The risky business of diversification. Read. Strateg. Manag. 1989, 57, 177-190. Available online: https://hbr.org/1979/05/the-risky-business-of-diversification (accessed on 22 September 2020). [CrossRef]

29. Burgelman, R.A.; Sayles, L.R. Inside Corporate Innovation: Strategy, Structure, and Managerial Skills; The Free Press: New York, NY, USA, 1986; pp. 1-216.

30. Tubke, A.; Saavedra, P.A.D.T.; Gonzalez, J.-L.G. Towards a first spin-off typology and a new concept for corporate spin-off research. Int. J. Technol. Transf. Commer. 2004, 3, 263. [CrossRef]

31. Zahra, S.A.; Van De Velde, E.; Larrañeta, B. Knowledge conversion capability and the performance of corporate and university spin-offs. Ind. Corp. Chang. 2007, 16, 569-608. [CrossRef]

32. Bruneel, J.; Van De Velde, E.; Clarysse, B. Impact of the type of corporate spin-off on growth. Entrep. Theory Pr. 2012, 37, 943-959. [CrossRef]

33. Fryges, H.; Wright, M. The origin of spin-offs: A typology of corporate and academic spin-offs. Small Bus. Econ. 2014, 43, 245-259. [CrossRef]

34. Hon, D.; Arthur, D.; Lee, J.; Lee, H. Study on vitalization of corporate entrepreneurship: Case study of corporate venturing. Korea Soc. Innov. Manag. Econ. 2014, 22, 311-332. [CrossRef]

35. Shane, S.; Venkataraman, S. The promise of entrepreneurship as a field of research. Acad. Manag. Rev. 2000, 25, 217-226. [CrossRef]

36. Eisenhardt, K.M. Building theories from case study research. Acad. Manag. Rev. 1989, 14, 532-550. [CrossRef]

37. Yin, R.K. Case Study Research: Design and Methods, 4th ed.; Sage: Newbury Park, CA, USA, 1994; pp. 1-282.

38. Creswell, J.W. Qualitative Inquiry \& Research Design, 3rd ed.; Sage: Newbury Park, CA, USA, 2013; pp. 111-128.

39. Merriam, S.B. Qualitative Research and Case Study Applications in Education, 2nd ed.; Wiley Jossey-Bass: San Francisco, CA, USA, 1998; pp. 27-43. Available online: http://www.appstate.edu/ \{\}jacksonay/rcoe/merriam. pdf (accessed on 22 September 2020).

40. Weick, K.E. The generative properties of richness. Acad. Manag. J. 2007, 50, 14-19. [CrossRef]

41. Strauss, A.; Corbin, J. Basis of Qualitative Research: Techniques and Procedures for Developing Grounded Theory, 4th ed.; Sage: Newbury Park, CA, USA, 1998.

42. Samsung Newsroom. Available online: https://news.samsung.com/kr/ (accessed on 22 September 2020).

43. Samsung Sustainability Report (2013-2020). Available online: https://www.samsung.com/sec/aboutsamsung/ sustainability/report-and-policy/ (accessed on 22 September 2020).

44. Don-A Business Review. Available online: https://dbr.donga.com/article/view/1201/article_no/9156/is_free/Y (accessed on 22 September 2020).

45. Lincoln, Y.S.; Guba, E.G. Naturalistic Inquiry; Sage: Newbury Park, CA, USA, 1985. 
46. Niels, B.; Donna, K. Global Entrepreneurship Monitor 2018-2019 Global Report; Global Entrepreneurship Research Association; London Business School: London, UK, 2019; pp. 1-152. Available online: https://www. gemconsortium.org/report (accessed on 22 September 2020).

47. Baek, H.K.; Bae, Z.T. Articles: A case study on the effective internal corporate venturing process in Korea. J. Small Bus. Innov. 1998, 1, 71-99.

48. Kuratko, D.F.; Hornsby, J.S.; Covin, J.G. Diagnosing a firm's internal environment for corporate entrepreneurship. Bus. Horiz. 2014, 57, 37-47. [CrossRef]

49. Abetti, P.A. The birth and growth of toshiba's laptop and notebook computers: A case study in Japanese corporate venturing. J. Bus. Ventur. 1997, 12, 507-529. [CrossRef]

50. Kuratko, D.F.; Covin, J.G.; Garrett, R.P. Corporate venturing: Insights from actual performance. Bus. Horiz. 2009, 52, 459-467. [CrossRef]

51. Birkinshaw, J.; Hill, S.A. Corporate venturing units: Vehicles for strategic success in the new Europe. Organ. Dyn. 2005, 34, 247-257. [CrossRef]

52. Burgers, J.H.; Jansen, J.J.; Van den Bosch, F.A.; Volberda, H.W. Structural differentiation and corporate venturing: The moderating role of formal and informal integration mechanisms. J. Bus. Ventur. (Special Issue Corp. Entrepreneurship) 2009, 24, 206-220. [CrossRef]

53. Sykes, H.B. The anatomy of a corporate venturing program: Factors influencing success. J. Bus. Ventur. 1986, 1, 275-293. [CrossRef]

54. Block, Z.; Ornati, O.A. Compensating corporate venture managers. J. Bus. Ventur. 1987, 2, 41-51. [CrossRef]

55. Keil, T.; McGrath, R.G.; Tukiainen, T. Gems from the ashes: Capability creation and transformation in internal corporate venturing. Organ. Sci. 2009, 20, 601-620. [CrossRef]

56. Gold, B. Silicon Valley Start-Ups and Corporate Innovation: Approaches to Resolve the Innovator's Dilemma; Springer Gabler: Wiesbaden, Germany, 2017; pp. 1-156. [CrossRef]

57. Morris, M.H.; Kuratko, D.F.; Covin, J.G. Corporate Entrepreneurship and Innovation, 2nd ed.; Cengage: Boston, MA, USA, 2010.

58. KISED (Korea Institute of Startup \& Entrepreneurship Development). A Study on the Development of Core Regulations and the Mitigation of the Burden in Each Stage of Start-up; Korea. 2016. Available online: https://www.kised.or.kr/board.es?mid=a10309000000\&bid=0008\&list_no=1843\&act=view (accessed on 22 September 2020).

59. Chandler, G.N.; Jansen, E. The founder's self-assessed competence and venture performance. J. Bus. Ventur. 1992, 7, 223-236. [CrossRef]

60. Timmons, J.A.; Spinelli, S. New Venture Creation: Entrepreneurship for the 21st Century, 10th ed.; McGraw-Hill: New York, NY, USA, 2009.

61. Kwon, S.J. Building a theory of Korean venture growth from cases: Opportunity pursuit mechanism driven by entrepreneurship, industrial environment, and government policy. J. Korean Entrep. Soc. 2018, 13, 140-166. [CrossRef]

62. Matzembacher, D.E.; De Barcellos, M.D.; Raudsaar, M.; Mets, T. Sustainable entrepreneurial process: From idea generation to impact measurement. Sustainability 2019, 11, 5892. [CrossRef]

63. Maurya, A. Running Lean, 2nd ed.; O’REILLY: Cambridge, UK, 2012; pp. 1-59. Available online: https: //leanstack.com/Running_Lean_Excerpt.pdf (accessed on 22 September 2020).

64. Barr, S.H.; Baker, T.; Markham, S.K.; Kingon, A.I. Bridging the valley of death: Lessons learned from 14 years of commercialization of technology education. Acad. Manag. Learn. Educ. 2009, 8, 370-388. [CrossRef]

65. Shane, S. Reflections on the 2010 AMR decade award: Delivering on the promise of entrepreneurship as a field of research. Acad. Manag. Rev. 2012, 37, 10-20. [CrossRef]

66. Lee, H.J. What factors are necessary for sustaining entrepreneurship? Sustainability 2019, 11, 3022. [CrossRef]

67. Wiklund, J.; Shepherd, D.A. Where to from here? EO-as-experimentation, failure, and distribution of outcomes. Entrep. Theory Pract. 2011, 35, 925-946. [CrossRef]

68. Lim, W.M. A blueprint for sustainability marketing: Defining its conceptual boundaries for progress. Mark. Theory 2016, 16, 232-249. [CrossRef]

69. Ben Youssef, A.; Boubaker, S.; Omri, A. Entrepreneurship and sustainability: The need for innovative and institutional solutions. Technol. Forecast. Soc. Chang. 2018, 129, 232-241. [CrossRef] 
70. Schaltegger, S.; Lüdeke-Freund, F.; Hansen, E.G. Business models for sustainability: A co-evolutionary analysis of sustainable entrepreneurship, innovation, and transformation. Organ. Environ. 2016, 29, 264-289. [CrossRef]

71. Lim, W.M. Creativity and sustainability in hospitality and tourism. Tour. Manag. Perspect. 2016, 18, 161-167. [CrossRef]

72. Lim, W.M. The sharing economy: A marketing perspective. Australas. Mark. J. (AMJ) 2020, $28,4-13$. [CrossRef]

Publisher's Note: MDPI stays neutral with regard to jurisdictional claims in published maps and institutional affiliations.

(C) 2020 by the authors. Licensee MDPI, Basel, Switzerland. This article is an open access article distributed under the terms and conditions of the Creative Commons Attribution (CC BY) license (http://creativecommons.org/licenses/by/4.0/). 